\title{
Agricultural Sciences Vs. Agricultural Engineering: An Overview
}

\author{
P.K. Paul ${ }^{1}$, R.R. Sinha' ${ }^{2}$ Anil Bhuimalli ${ }^{3}$, K.S. Tiwary ${ }^{4}$, Bashiru Aremu ${ }^{5}$ and Pappachan Baby ${ }^{6}$ \\ ${ }^{1}$ Executive Director, MCIS, Department of CIS, Information Scientist (Offg.), Raiganj University, India, Asia \\ ${ }^{2}$ Pro Vice Chancellor (Asian Region), Commonwealth Vocational University, Kingdom of Tonga, Oceania \\ ${ }^{3}$ Vice Chancellor, Raiganj University, West Bengal, India, Asia \\ ${ }^{4}$ Dean (Science \& Management), Raiganj University, West Bengal, India, Asia \\ ${ }^{5}$ Vice Chancellor, Crown University, Intl. Chartered Inc. (CUICI) Argentina Campus, South America \\ ${ }^{6} \mathrm{Head}$ (Asian Region), Ballsbridge University, Commonwealth of Dominica, North America \\ *Corresponding author: pkpaul.infotech@gmail.com
}

Received: 20 Sept., 2020

Revised: 12 Nov., 2020

Accepted: 05 Dec., 2020

\begin{abstract}
Agriculture is one of the important and valuable facets in the world as for the survival we need the foods and from agriculture it has come from. Therefore Agriculture Science is important and consider as most for the betterment of the agriculture in scientific way. Initially Agriculture considered only a tool or way for the crop development and gradually it is become a field of study. Agricultural Science is about the study of plants, pathogens, pests, herbs, chemicals and various physiological properties in better and healthy crops, plants, and vegetable products development with the context of Agriculture sustainable. Agricultural Science is considered as important and valuable applied science deals with suitable methods, tools for the development of agricultural products and foods even including animal cultivation. After the development of Agricultural Science many other allied and related branches have been developed viz. Agricultural Engineering, Agricultural Management, and Agricultural Biotechnology etc. Agricultural Engineering is focused with the designing, construction, development of the farming equipments, products, machines, tools etc. for the agricultural development and agricultural unit management. The field is dedicated also in scientific study, experiments, research, evaluation related to the Agricultural Systems. This paper is about the aspects of Agricultural Science and Agricultural Engineering including their features, attributes, natures, functions and roles and so on. Further the paper also deals with the job potentialities of the field as well.
\end{abstract}

Keywords: Agricultural Science, Agricultural Engineering, Agricultural Development, Farming, Cultivation, Agricultural Productivity

Agriculture in simple sense is the way for producing various foods and products such as corps, vegetables, plants etc. Later other components also been added into the Agriculture viz. timber, fertilizers, sugar, 
alcohol, tropical fish, wool, cotton and so on. Worldwide a majority of the workers and professionals are engaged with various types of agricultural professions. And, study considered that Internationally 11 regions are treated as agricultural productive and engaged. Once only plants and vegetables treated with the agricultural products and radically animals also treated as agricultural products with close connections with the animal sciences and husbandry. Gradually the aspects of the environment also been considered as important in agriculture including in global warming, natural disaster etc. Initially only Agricultural Science considered as important and vital as a field of study. Though, the first use of agricultural engineering was the introduction of irrigation for the large scale agriculture. Apart from these the increasing uses of the tractors and machines during the industrial revolution may be consider as important step in Agricultural Engineering began. According to the expert during the industrial revolution other devices become popular and being used viz. mechanical harvesters and planters for the cultivation of the food and crop industries etc. (Cacek et al. 1986; Gattinger et al. 2012). The increasing applications of the engineering concepts, tools, products and devices into agriculture boost in the productivity of crops and other products and a separate identical field has been started i.e. Agricultural Engineering.

\section{Objective}

The present paper entitled on 'Agricultural Sciences Vs. Agricultural Engineering: A Study' is proposed with following aim and objectives (but not limited to)-

$\square$ To know about the basics of Agricultural Science including its basics, features and characteristics.

$\square$ To learn about the Basics attributes and characteristics of the Agricultural Engineering including its emergence.

$\square$ To learn about the emerging methods of Agriculture and in the context of Agricultural Science and Agricultural Engineering.

$\square$ To know about the basic job opportunities in the field of Agricultural Engineering with reference to the areas of field of study.

\section{Agricultural Science: Basics and Development}

As an Applied Science, Agricultural Sciences is concern about various scientific principles, methods, tools etc. The field also treated as a science and art dedicated in cultivation of multiple products viz. crops, plants and even livestock and animals etc. The sedentary human civilizations enable people for the foods and survive by the initiation of the agriculture. The field of Agricultural Science though started later on but the concept regarding the agriculture started about thousands years ago and about 105,000 years ago. Furthermore the nascent farming was started before 11,500 years and gradually various kinds of animals also being part of agriculture. After that various kind of animals like pigs, sheep and cattle etc. become domesticated around 10, 000 years ago. Gradually the development of Agricultural Sciences leads the promotion in many respects. Furthermore various other branches and areas considered important and allied in Agricultural Sciences and among these important are Mechanical Engineering, Food Technology, Information and Communication Technology, Genetic Engineering, and so on. For example the field Genetic Engineering in the agricultural changed the picture traditional Agricultural in many respect 
(Darnhofer et al. 2005; Mäder et al. 2002; Stockdale et al. 2002). Apart from the technologies the field chemistry also play a leading role in agriculture and notable changes are include-

$\square$ By the uses of the chemical fertilizer.

$\square$ In use of chemical insecticides.

$\square$ In healthy chemical fungicides.

$\square$ For the purpose of the soil makeup and development.

$\square$ Regarding the agricultural products etc.

Therefore Agricultural Science is an interdisciplinary area. And it is more than biology and combines with other areas viz. Management, Commerce and Economics and so on.

\section{Agricultural Science: Areas and Nature}

Agricultural Science is an emerging and interdisciplinary field and as far as biological areas are concerned few important are depicted in Fig. 1.

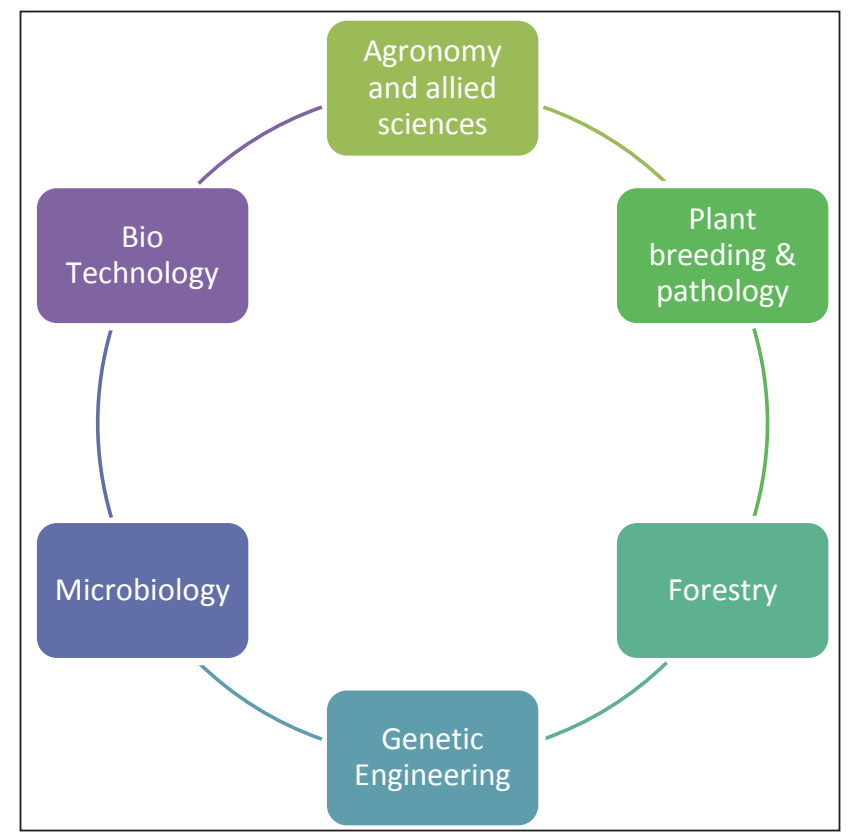

Fig. 1: The Biological areas of Agricultural Sciences and Technology

Therefore Agricultural Science is a kind of technique and procedure and gradually it has become a field of study with having various features and attributes viz.-

$\square$ Agricultural Science is a broad field of practice connected with various other fields and subjects all together.

$\square$ It is an interdisciplinary studies connected with areas from Science, Engineering, Technologies, Management and Commerce etc. 
$\square$ Therefore Agricultural Sciences is a multidisciplinary one and solve the agricultural problem scientifically.

$\square$ Agricultural Science is applicable in production of the foods, agro products, animal etc. and hence it is an Applied Science.

$\square$ Apart from the biology the field Agricultural Science also connected with the economic science, social sciences for its various operations related to the agriculture.

$\square$ Emerging subjects and areas like agronomy, plant breeding, genetics, soil sciences, microbiology etc. are considered as important and valuable in proper Agricultural Science development.

$\square$ It is the study of pests and their management also for healthy and sustainable agricultural practice; moreover it doesn't deals with the environmental effects viz. waste management, horticulture, soil degradation and so on.

$\square$ Agricultural Sciences is also available as an Engineering nomenclature with Agricultural Engineering and in some context, Agricultural Science and Technology.

$\square$ The field is highly connected with Management Sciences due to agricultural systems, cultivation and products management (Hole et al. 2005; Ramesh et al. 2005; Paul et al. 2019).

$\square$ The latest technologies viz. Genetic Engineering, Information and Communication Technology, Nanotechnology are become important and valuable subject in this context.

Agricultural Systems become changes rapidly in recent past there are various aspects and methods in agriculture due to recent applications of the scientific methods, applications and so on viz. Agricultural chemistry is responsible for use of the chemical fertilizer, insecticides including chemical fungicides in cultivation etc. Regarding the soil makeup, soil health also Agricultural Chemistry considered as important and it is treated as important in Agricultural Science. Another aspect i.e. Green Revolution in the Western world spread huge changes the entire world include hydroponics, plant breeding, hybridization, gene manipulation, better management of soil nutrients, and improved weed control. And here also Agricultural Science played a leading role. Though the partial role of Engineering i.e. Agricultural Engineering is also applicable in traditional Agricultural Science and changed its arena and led few other attributes viz. Genetic engineering based Agriculture - and it is applicable in agro products, crops, household animal product development using genetic engineering principles, tools, methods etc.

Similarly due to the Agricultural Science promotion with other technologies another system been developed viz. Organic Agriculture in which agricultural systems very minimum or less harmful chemical are used viz. less pesticides, fertilizers, antibiotics, growth hormones etc. and rapidly growing in modern agro production practices. Corporate Agriculture is farming and done by the mega corporations and largescale farms and in this kind of agriculture corporate bodies are directly engaged in the cultivation; and here more human resources are engaged. This kind of agriculture practiced for the immediate profit also. Vertical Farming is another method in which corps, vegetables etc cultivated in the stacked layers, vertically (Darnhofer et al. 2010; Murphy et al. 2007; Pang and Letey, 2000). Hence, it is the solution of the space problem and in a particular area and even building floor etc. cultivation become possible. Therefore Agriculture is a broad field and not only consists with the Agricultural Science and Agricultural Engineering but also other fields, as depicted in Fig. 2. 


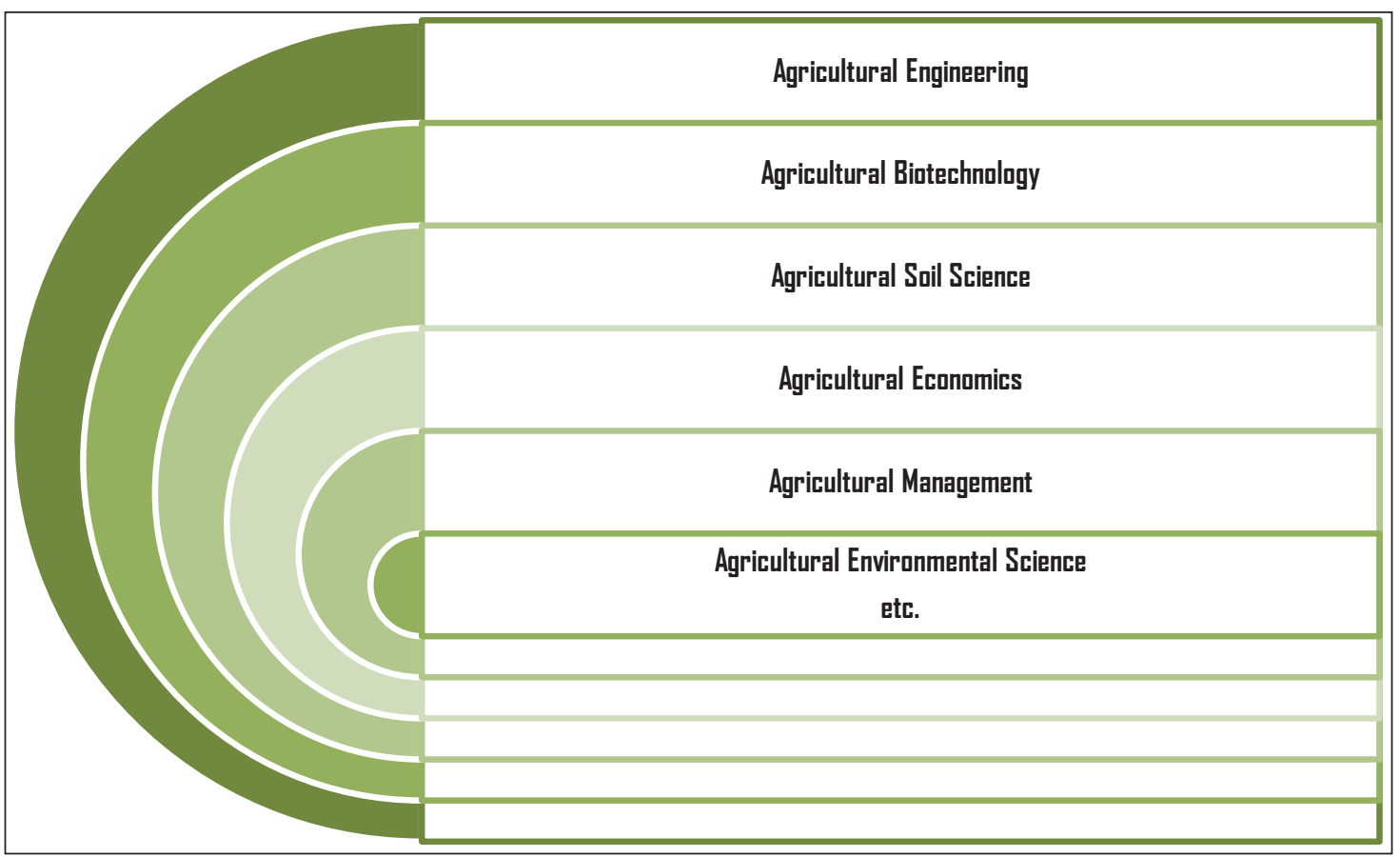

Fig. 2: The world of Agricultural Sciences

\section{Agricultural Engineering: Need}

Agricultural Engineering is a diverse field and responsible for the designing and development of the Agricultural products, tools and systems for healthy Agricultural Systems (Genius et al. 2006; Peigné, et al. 2007; Sunding and Zilberman, 2001). The following description well noted on this-

Agricultural Engineering is allied with the Agricultural Science and responsible for the designing, development of the cultivation with equipments, products, machines, and so on. It is an engineering field of farming and cultivation and dedicated in newer designing, development of the agro systems; and modification and also improvement of existing systems as well. The development of various items viz. dams, water reservoirs, agro tractors etc. Agricultural Engineering is also connected with the environmental management for healthy agricultural development including-

Agricultural waste systems and development.

$\square$ Sustainable agricultural product designing.

$\square$ Development of Biofuels from non-food resources etc.

Agricultural Engineering is also engaged in food storage systems development, food processing system development, agro plants design and development, water and water pollution system maintenance and development etc. Agricultural Engineering is also engaged in the agricultural waste-to-energy systems and so on. 


\section{Applications and Context of Agricultural Engineering}

Therefore it is a hardcore field and restricted in Agriculture and other areas and purely responsible in developing the systems, tools and products etc. viz.-

Agricultural Engineering is responsible for the hardcore engineering solutions in respect of agriculture including irrigation, drainage systems, flood management systems, water-control mechanism and so on (Johnson et al. 2016; Paul, 2013; Picard and Zeng, 2005).

Agricultural Engineering is may consider as a scientific study and research area especially for the practice in agro related fields.

$\square$ Agricultural Engineering is also engaged in designing and development of agricultural buildings required and consider as part of the agricultural systems.

The agricultural systems including spraying, harvesting, and transportation systems, marketing system etc. may be considered as an important activity of the Agricultural Engineering.

$\square$ Agricultural Engineering needed in equipment design, farming system management regarding agriculture.

$\square$ Agricultural Engineering dedicated in the advocating, developing, implementing, mechanism development for the new ways of farming, harvesting, and storage.

$\square$ In the development of the land, water and other uses including developing healthy agricultural resource management.

$\square$ Agricultural Engineering needed in sophisticated water management and conservation systems development including in soil management, erosion control, seeding, livestock production and so on.

Agricultural Engineering needed in animal farm management with proper mechanism following engineering and management international standards (Gunapala and Scow, 1998; Oehl et al. 2004; Stolze and Lampkin, 2009).

Agricultural Engineering areas are growing internationally; even other branches such as physical and chemical properties also valuable and in this regard other areas play a leading role viz. Bio Technology, Food Engineering, Environmental Engineering, etc. (Klerkx and Leeuwis, 2009; Ramesh et al. 2010). There are different areas of the field and some of these are depicted in Table 1.

Due to the importance of the Agricultural Engineering various job opportunities have been created such as Agricultural Engineers (They are responsible for the design and development of the agricultural machinery, equipments, designing of food processing units, operations etc), Agricultural Inspector (Such professionals are look after the aspects and issues of laws, rules and regulations related to the agricultural systems, food quality and safety. They are also look after the issues of quality standards), Agricultural Specialist (They are knowledgeable in agriculture and practice of the agriculture systems) Farm Shop Manager (Such professionals are engaged with the overall technical, and managerial aspects of the farm and agricultural units; even sometimes they do driving tractors, operating machinery, feeding livestock or spraying fields) Food and Beverage Expert (They are normally engaged with the monitoring of food and beverage; including they are also dedicated in recruitment, training, scheduling of the staffs), Agronomist (Such Professionals are dedicated in crop rotation, irrigation \& drainage, planet breeding, soil science, weed control \& disease \& pest control), Survey Research Agricultural Engineer (They are primarily 
engaged with the assessing the environmental impact of agricultural production, look after construction projects, solving engineering problems etc.) (Gattinger et al. 2012; Watson et al. 2002).

Table 1

\begin{tabular}{|c|c|c|c|}
\hline \multicolumn{4}{|c|}{ Agricultural Engineering \& Areas } \\
\hline$*$ & Engineering Chemistry & $*$ & Kinematics and Dynamics \\
\hline$*$ & Engineering Physics & 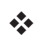 & Crop Production \\
\hline$*$ & Mathematics & 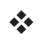 & Hydrology \\
\hline$*$ & Engineering Mechanics & $\nLeftarrow$ & Kinematics and Dynamics \\
\hline$*$ & Basic Electrical Engineering & 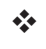 & Electrical Machines \\
\hline$*$ & Engineering Graphic & $\nLeftarrow$ & Agriculture Engineering Structures \& Rural \\
\hline$*$ & Introduction to Computing & & Engineering \\
\hline$*$ & Environment and Ecology & $*$ & Post-Harvest Engineering \\
\hline$*$ & Engineering Thermodynamics & 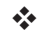 & Soil and Water Conservation Engineering \\
\hline$*$ & Basic Electronics & $*$ & Building Materials and Structural Design \\
\hline$*$ & $\begin{array}{l}\text { Numerical Analysis \& Computer Programming } \\
(\mathrm{C}, \mathrm{C}++)\end{array}$ & & $\begin{array}{l}\text { Agriculture Engineering Structures and Rural } \\
\text { Engineering }\end{array}$ \\
\hline$*$ & Material Science & 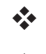 & Post-Harvest Engineering \\
\hline$*$ & Strength of Materials & $*$ & Pumps Engineering \& Hydraulic Control \\
\hline$*$ & Fluid Mechanics & $*$ & Irrigation Engineering \\
\hline$*$ & Soil Science & $*$ & Farm Machinery \\
\hline$*$ & Computer Programming & $*$ & Refrigeration and Air-conditioning \\
\hline$*$ & Soil Science Lab & $\star$ & Pumps Engineering \& Hydraulic Control \\
\hline$*$ & Hydrology & $*$ & $\begin{array}{l}\text { Instrumentation and Control Engineering in } \\
\text { Agriculture }\end{array}$ \\
\hline$*$ & Soil Mechanics & & \\
\hline$\star$ & Farm Machinery / Irrigation Engineering. & & \\
\hline
\end{tabular}

The employment opportunities in Agricultural Engineers are also changing rapidly and increasing day by day. Among the common and suitable positions few important are include (but not limited to) -

$\square$ Non-government voluntary organizations

$\square$ Department of Transportation and Agriculture

$\square$ In Tea gardens

$\square$ As Farming and Agricultural Consultants

$\square$ Agro Area development projects

$\square$ In Agricultural machinery organizations

$\square$ In Dairy industries

$\square$ In Agricultural finance organizations.

$\square$ Processing agricultural products

$\square$ In Educational Institutes including Agricultural Universities

$\square$ In Water and Environmental management and so on. 
The aspects and areas of the Agricultural Engineering also changing and become closer with another area called Agricultural Information Technology, Agricultural Informatics etc. for the development of the Smart and Digital Agriculture. Therefore Agricultural Informatics may also consider as important and part of the Agricultural Engineering.

\section{Major Findings}

Therefore Agricultural Sciences is deals with the crop production process, scientific study including the pest management, soil science, agronomy, horticulture, technology and so on. Agricultural Engineering may be consider as a wider branch and following may be consider as important and valuable with following few major areas-

\section{$\square$ Farm machinery and Power Engineering \\ $\square$ Irrigation Management and Engineering \\ $\square$ Soil and water Engineering and Management \\ $\square$ Harvesting and Food Processing Technology.}

$\square$ Agro and Environmental Engineering etc. (Tovey, 1997; Bond and Grundy, 2001; Paul et al. 2015). Thus, Agricultural Engineering deals with various equipments and systems knowledge such as irrigation, pumps, wells, tube well etc. Therefore in farm operations, Agriculture sustainable system development also this is may be offered well.

Agriculture Science is an applied sciences related to the agronomy, horticulture and soil science apiculture, entomology etc. and other biological sciences. Other Engineering Sciences such as Electrical, Civil and Mechanical Engineering etc. are very close with the Agricultural Engineering indirectly. Therefore irrigation, environmental sciences, soil and water engineering, food processing plants and food storage management etc. are the major aspects in the field. There are many relationships with Agricultural Engineering with the Agricultural Science and thus may are employed in vice versa. According to a study most of the agricultural engineers are employed with traditional hardcore engineering and it is about $17 \%$ whereas $16 \%$ are engaged with the technology management and policy and government and another $14 \%$ engaged with the food manufacturing. As per the study $13 \%$ are engaged in the construction, mining machinery. However about $6 \%$ are engaged with the education and teaching (Padel, 2001; Paul et al. 2015).

\section{CONCLUSION}

Agriculture Science is an applied, interdisciplinary, multidisciplinary field of study dedicated in agricultural scientific study, research and developing new methods and tools. Whereas, Agriculture Engineering is close to only hardcore engineering and designing and development of the agricultural products, systems and mechanism. However, Agricultural engineers work both indoors and outdoors and also engaged with the plans and managing projects, in agricultural settings, water management projects and so on. Both the fields are very much close with the Agricultural Informatics as well and do the plans and solve problems effectively and mutually. Both the subjects are used not only by the horticulturalists, agronomists, animal scientists, and geneticists but also policy makers etc. For the solid and sustainable development both the subjects are required. However in certain context similar and combined Agriculture Science and Engineering / or Agriculture Science and Technology nomenclature are noticeable. 


\section{REFERENCES}

1. Bond, W. and Grundy, A.C. 2001. Non-chemical weed management in organic farming systems. Weed research, 41(5): 383-405.

2. Cacek, T. and Langner, L.L. 1986. The economic implications of organic farming. American Journal of Alternative Agriculture, 1(1): 25-29.

3. Darnhofer, I., Lindenthal, T., Bartel-Kratochvil, R. and Zollitsch, W. 2010. Conventionalisation of organic farming practices: from structural criteria towards an assessment based on organic principles. A review. Agronomy for Sustainable Development, 30(1): 67-81.

4. Darnhofer, I., Schneeberger, W. and Freyer, B. 2005. Converting or not converting to organic farming in Austria: Farmer types and their rationale. Agriculture and Human Values, 22(1): 39-52.

5. Gattinger, A., Muller, A., Haeni, M., Skinner, C., Fliessbach, A., Buchmann, N., ... \& Niggli, U. 2012. Enhanced top soil carbon stocks under organic farming. Proceedings of the National Academy of Sciences, 109(44): 18226-18231.

6. Genius, Margarita, Christos J. Pantzios, and Vangelis Tzouvelekas. 2006. Information acquisition and adoption of organic farming practices. Journal of Agricultural and Resource Economics, 31(1): 93-113.

7. Gunapala, N. and Scow, K.M. 1998. Dynamics of soil microbial biomass and activity in conventional and organic farming systems. Soil Biology and Biochemistry, 30(6): 805-816.

8. Hole, D.G., Perkins, A.J., Wilson, J.D., Alexander, I.H., Grice, P.V. and Evans, A.D. 2005. Does organic farming benefit biodiversity?. Biological Conservation, 122(1): 113-130.

9. Johnson, N.L., Kovarik, C., Meinzen-Dick, R., Njuki, J. and Quisumbing, A. 2016. Gender, assets, and agricultural development: Lessons from eight projects. World Development, 83: 295-311.

10. Klerkx, L. and Leeuwis, C. 2009. Establishment and embedding of innovation brokers at different innovation system levels: Insights from the Dutch agricultural sector. Technological Forecasting and Social Change, 76(6): 849-860.

11. Murphy, K.M., Campbell, K.G., Lyon, S.R. and Jones, S.S. 2007. Evidence of varietal adaptation to organic farming systems. Field Crops Research, 102(3): 172-177.

12. Mäder, P., Fliessbach, A., Dubois, D., Gunst, L., Fried, P. and Niggli, U. 2002. Soil fertility and biodiversity in organic farming. Science, 296(5573): 1694-1697.

13. Oehl, F., Sieverding, E., Mäder, P., Dubois, D., Ineichen, K., Boller, T. and Wiemken, A. 2004. Impact of long-term conventional and organic farming on the diversity of Arbuscular mycorrhizal fungi. Oecologia, 138(4): 574-583.

14. Padel, S. 2001. Conversion to organic farming: a typical example of the diffusion of an innovation?. Sociologia Ruralis, 41(1): 40-61.

15. Pang, X.P. and Letey, J. 2000. Organic farming challenge of timing nitrogen availability to crop nitrogen requirements. Soil Science Society of America Journal, 64(1): 247-253. 
16. Paul, P.K., Aithal, P., Sinha, R., Saavedra, R. and Aremu, B. 2019. Agro Informatics with its Various Attributes and Emergence: Emphasizing Potentiality as a Specialization in Agricultural Sciences-A Policy Framework. IRA-International Journal of Applied Sciences, 14(4): 34-44.

17. Paul, P.K. 2013. Information and Knowledge Requirement for Farming and Agriculture Domain. International Journal of Soft Computing Bio Informatics, 4(2): 80-84.

18. Paul, P.K. et al. 2015. Agricultural Problems in India requiring solution through Agricultural Information Systems: Problems and Prospects in Developing Countries. International Journal of Information Science and Computing, 2(1): 33-40.

19. Paul, P.K. et al. 2015. Information and Communication Technology and Information: their role in Tea Cultivation and Marketing in the context of Developing Countries-A Theoretical Approach. Current Trends in Biotechnology and Chemical Research, 5(2): 155-161.

20. Peigné, J., Ball, B.C., Roger-Estrade, J. and David, C.J.S.U. 2007. Is conservation tillage suitable for organic farming? A review. Soil Use and Management, 23(2): 129-144.

21. Picard, P.M. and Zeng, D.Z. 2005. Agricultural sector and industrial agglomeration. Journal of Development Economics, 77(1): 75-106.

22. Ramesh, P., Panwar, N.R., Singh, A.B., Ramana, S., Yadav, S.K., Shrivastava, R. and Rao, A.S. 2010. Status of organic farming in India. Current Science, pp. 1190-1194.

23. Ramesh, P., Singh, M. and Rao, A.S. 2005. Organic farming: Its relevance to the Indian context. Current Science, 88(4): 561-568.

24. Stockdale, E.A., Shepherd, M.A., Fortune, S. and Cuttle, S.P. 2002. Soil fertility in organic farming systems-fundamentally different?. Soil Use and Management, 18: 301-308.

25. Stolze, M. and Lampkin, N. 2009. Policy for organic farming: Rationale and concepts. Food Policy, 34(3): 237-244.

26. Sunding, D. and Zilberman, D. 2001. The agricultural innovation process: research and technology adoption in a changing agricultural sector. Handbooks in Economics, 18(1A): 207-262.

27. Tovey, H. 1997. Food, environmentalism and rural sociology: on the organic farming movement in Ireland. Sociologia Ruralis, 37(1): 21-37.

28. Watson, C.A., Atkinson, D., Gosling, P., Jackson, L.R. and Rayns, F.W. 2002. Managing soil fertility in organic farming systems. Soil Use and Management, 18: 239-247. 